\title{
3 \\ "Showing commitment" and emotional management
}

Excerpt from interview:

Teun: Eventually we found a fairly big squat that was on sale. We spent a month sorting it out; how long it had been empty, if there were options of buying. We were doubting if it was really empty because there was a lot of stuff in there. Eventually we decided to squat it. The squatting group told us to wait a week because they were having a party. We squatted it a week after and two days before we squatted it, it was sold. So we broke open the door and occupied it through the summer. The new owner was a dodgy Christianity group.

Nazima: Why was it dodgy?

Teun: It's a very ... the house they owned it, they put, they make it for students to live in. For Christian students to live in and they make a package deal. They rent the rooms, including the food, including the obligation as well to spend their amount of time into Christianity ... They are very strict in it as well. It's not ... in my opinion, they put a lot of bindings ... They've got this twenty page list of things you should live by if you want to rent a room from them. And in my opinion, that's ... I don't find that very honest. Or giving people a bit of freedom. And I think that is a very wrong way to convince people of Christianity.

This chapter presents a cartography of internal power dynamics within the intimate space of squatted houses. Squatted houses are fundamental to the structure of the squatters movement in Amsterdam. Living groups within squatted households who identify as part of the squatters movement, ${ }^{1}$ consequently both reflect and refract larger movement dynamics of hierarchy and authority. They reflect the standards of a larger movement in the sense that one's squatter capital contributes to one's status position within a squatted household. They refract in that within a household, the highest values are to maintain a lively and peaceful group dynamic, silently maintain the unspoken hierarchies within a group without challenging them, and thereby avoid tension and conflict. Whereas in both the front stage and the 


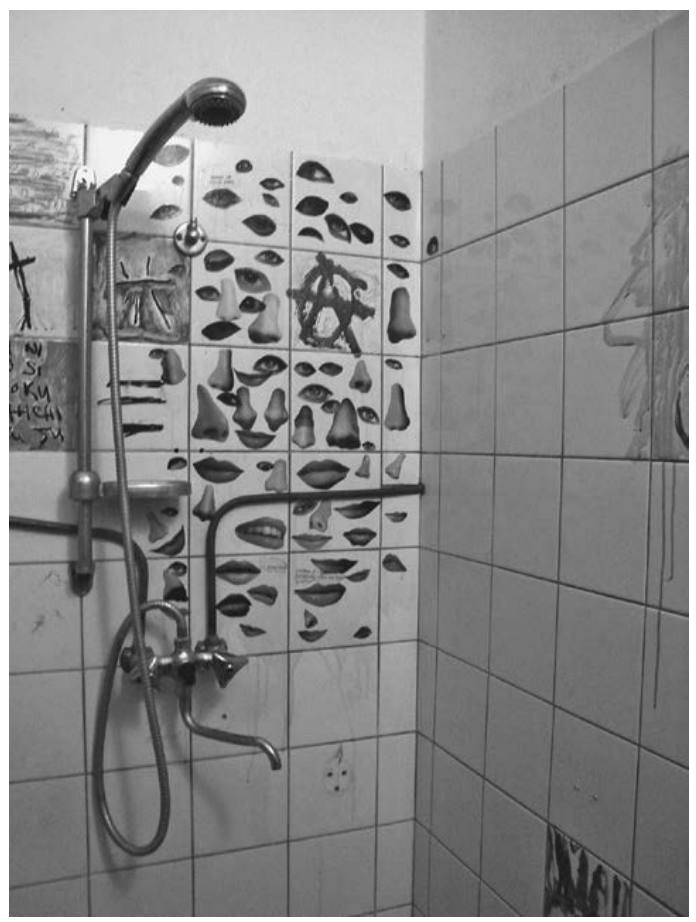

Figure 3.1 Shower inside of a squat, 2006

backstage of the movement, being an outspoken and argumentative persona brings status and capital, such traits should be minimized within a living group to promote a cohesive and peaceful home life.

In this chapter, I first argue that authority comprises a combination of having organized and originally squatted a house, seniority, and consistently "showing commitment." I highlight a range of squats: from the most "active" in the movement to a squat that vigorously repudiates the movement's ideals and social values. In these portraits of authority, one sees how authority figures practice their dominance in a group, how they express expectations of others, encompassed in the term, "showing commitment," and how housemates with lesser status negotiate this terrain of unstated hierarchy. Moreover, I examine the term "showing commitment," using Arlie Hochschild's concept of emotional management. The act of showing commitment is deliberately a vague and ambiguous term because it depends on the authority figures in the group to determine what it means to show commitment while simultaneously denying that they possess this authority. Further, authority figures are exempted from "showing the commitment" that they desire of others. 
I then discuss how people who were invited to move into a house after its squatting hold authority because of their skills and squatter capital. Following this, I describe the story of Karima, an undocumented East African woman who lived in a squatted house as a guest and unusually for an undocumented person, participated in the squatter community. Due to her personhood rupturing the normative "feeling rules" in this community, in which people felt pity for her rather than a fictitious sense of equality, the living group did not invite her to become a housemate, leading her to move out of the squatters' community. The final part of this chapter discusses the consequence of not taking authority in these liminal spaces and how in such cases squatted houses are often taken over by heroin users.

\section{Squatting a house as the constitutive act of authority making}

In the squatters movement, squatting one's own house is the first and most pivotal step in being recognized as a "real" or authentic squatter. Within a living group, those who squatted a house hold the position of the most authority. One Sunday, I attended two squatting actions held after one another. The first squatting action, of an empty eighteenth-century building in the center of Amsterdam by a group of four people, failed because after the group broke open the door, they found evidence of a resident, including freshly purchased food in the refrigerator and a warm and unmade bed. Everyone present fled to avoid arrest.

The second house was squatted by a different group of four people who had originally only intended to occupy one floor but unexpectedly found themselves with a three-story apartment building with a colossal ground floor space. At this second action, I asked Mario, a Romanian student from the first failed squatter group, who had been participating in the movement for less than a year, if his group could move into this second house. $\mathrm{He}$ said, "Well, I don't think so. Darius [a squatter from the second group who organized the action] is well, Darius [implying that Darius disliked him and that Darius is a difficult person]. And you know. Its property." Mario's statement indicated that despite the squatters movement's disavowal of property, because Darius had organized the action and had successfully squatted the house, the house became his property in the social dynamics of the movement. Mario's remark also demonstrates how quickly participants in this subculture learn its unstated rules.

In an anti-authoritarian and anti-hierarchical subcultural milieu, this hierarchical dynamic is rarely discussed openly. Instead, it's referred to obliquely by housemates with less status who moved in after the house was squatted while those who hold authority positions deny the existence of 
such dynamics. In one house I moved into a few months after it had been squatted, one housemate, Alicia, had been a member of the original group who squatted the house. After the first week of occupation, she never actually moved in to her room, instead staying with her boyfriend in a rented house. After four months of the squat's existence, her room remained empty, a fact that I found shocking amid the housing shortage.

Marie, a veteran squatter with ample squatter capital who lived in the movement for over ten years and had organized the squatting action, often complained to the housemates and the members of the squatters' community about Alicia's absence while never confronting her directly. Another housemate, Joris, groused incessantly about Alicia's empty room - again, in her absence - mainly because he wanted to live in the light-filled, spacious room with exceptional privacy. Arjen, a veteran squatter in his late forties who had also moved in months after the squatting of the house, once snapped at Joris in front of me, "There is no point in complaining to me about Alicia. If you want her out, you know that Marie is the one who has to make the decision." Despite a number of housemates feeling disgruntled about Alicia's empty room, the members of the group felt that Marie was the only person entitled to ask Alicia to move because she had organized the squatting action.

In a different house where I resided, Dana, a housemate with substantial squatter capital as a reliable and responsible person who efficiently organizes actions, announced suddenly that she had found another house to squat and that she planned to move the following week. In private discussions about why she had decided to leave (no one asked her directly) between myself, Roel (who had originally squatted the house), and Samuel, a veteran squatter who moved in afterwards, Samuel said, "Well, she moved in after the house was squatted and I guess she was tired of not getting her way with how the house runs." Roel, holding the position of most authority, responded by fervently denying the existence of such a hierarchy.

\section{Living groups and "showing commitment"}

Living groups are communal living structures in which people commit to living together cooperatively as an alternative to residing alone or in a family structure. There is an expectation that housemates eat meals together, contribute equally towards household expenses, spend time together, and somewhat share their lives with the people with whom they reside. There are different standards for living groups than for residing in a group or a student house, in which each individual's room is their private space, only sharing the kitchen and bathroom when necessary, and without expectation of emotional connection. In the United States, living groups are referred to as communes, with the connotation that such groups exist mainly in 
the countryside in contrast to squatter living groups in Amsterdam, which are urban. Living groups exist outside the squatters movement in the Netherlands, including in the social housing system and the private market.

Living groups are thorny structures because an expectation exists of cooperatively sharing household tasks and expenses while demonstrating and genuinely feeling an emotional commitment to the group and to one's housemates. In squats, communal living is further complicated because of the disjuncture between the ideal of a living group - mutual responsibility, cooperation, and emotional connection - and the lifestyle choices and interests of most people who choose to squat.

One essential component of communal living is the equal partaking of household tasks and finances. Yet the inherent contradiction is that a number of people choose to squat to avoid performing such tasks and financial accountability. Washing dishes, cooking, food shopping, cleaning, purchasing household supplies; such tasks are the daily, mundane, and necessary components of communal living. They seem too boring and repetitious for squatters who are only interested in the thrills of actions or lack the capacity to complete such tasks.

The same principle counts for financial accountability. A number of people squat to avoid financial responsibilities and paid employment. Many squatters who have paid jobs prefer not to spend their earnings on communal expenses. They are saving money for trips or simply use their wages on expenses such as vacations, partying, drinking, and drugs. Larissa, a veteran squatter commented, "The other day, we had a dinner party and a friend of Jan said, "Oh, you guys must save a lot of money since you don't pay rent." We all just looked at each other and like, uh, hmmm. Then Joseph joked, "If I saved my money, how would I pay for my drugs?",

The term "showing commitment" can only be understood in a context in which the majority of people do not want to commit. The fact that the behavior associated with showing commitment is highly valued means that it's uncommon among the majority of squatters. I have often heard this expression in two modes: first, as a critique in which someone is described as not showing commitment by never spending time in the squat, cooking, cleaning, etc. Second, as a way to explain someone's motivations, as in the following remark about Teun, who had docked his sailboat in a cavernous squat, "He goes there every weekend to help with the repairing of their dock to show commitment." In this case, in exchange for the housemates of this squat allowing Teun to dock his sailboat in their house, Teun had to "show commitment" by helping with the building project of repairing their dock. By spending time in the space and working on a communal project with this group, Teun demonstrated his gratitude, that he was communally minded, and possessed squatter skills.

Showing commitment is tricky because it's ambiguous, open to interpretation, depends on the person who purposely "shows commitment," and the 
recognition of the people to whom one endeavors to show commitment. In a living group, showing commitment often signifies investment symbolically in the house and emotionally to the group. It is made up of concrete deeds: regularly cooking, cleaning, shopping, repairing (thus, why a reliable and skilled builder is highly sought as a housemate), occupying, barricading, generally taking care of a house, and being financially reliable. Other ways of showing commitment is to manage the legal defense of a house: working with the lawyer, organizing the paperwork, campaigning, researching, arranging the court case, etc. Idealistically, the act of showing commitment is intended to be inherently altruistic and communal, benefiting the group versus solely serving one person - like cooking for oneself and eating alone in one's room.

The second part of showing commitment seems more complicated because it refers to an emotional connection that may or may not exist. As for household deeds, others have to recognize this emotional connection and define it as "showing commitment." Emotional connections are demonstrated via a general hanging around and an effort to spend time with, show interest in, and bond with one's housemates. This expectation lies at the heart of the living group ideal in its attempt to create an alternative to the perceived alienating models of the nuclear familiar or of living alone.

Between the obligations of squatter living groups, movement expectations, and the fact that one resides precariously in a house that could at any time be evicted, this type of lifestyle can easily become all encompassing. Such expectations allow little room for other activities, for example, being an artist or a student, two groups attracted to squatting and the freedom enabled through no rent housing.

Consequently, performing a genuine emotional connection becomes fraught due to the larger context. First, the housing shortage in Amsterdam signifies that a number of people - students and artists in particular - desperately seek low-cost housing. Therefore, when such people reside as guests in squats or are allowed to remain as housemates, a power dynamic exists between these people and the ones who squatted the house who granted them a residence. Thus, an unacknowledged dynamic of gratitude and dependency is masked behind a fiction of equality and radical left communal living. Since this power dynamic exists, but cannot be discussed, those who hold authority have expectations of people who they invite to live with them, but often express such desires circuitously rather than transparently. Furthermore, authority figures are exempt from the conditions they demand of others; unless those with less status challenge them, creating conflict which proves antithetical to having a peaceful home life.

The power dynamics of squatter living groups are inherently convoluted but well worth the difficulty of unpacking. Arlie Hochschild (1979), the pioneering feminist sociologist, coined the concept of emotional management, which encompasses the concepts of emotion work, emotional labor, and 
feeling rules. Hochschild argues that in service-oriented professions, particularly those associated with or dominated by women, an essential aspect of these jobs are to manage one's emotions and of one's co-workers and clients. This facet of the jobs tends not to be discussed but are intrinsic to these professions and are productive of stereotypical gender roles, such as emotional care in nursing, or the types of client interface required of airline flight attendants.

Emotion work describes the process of either masking one's emotions to give a different impression (surface acting) or actively internally changing how one feels to enable a symmetry between one's internal emotional state and the impression that one transmits to others (deep acting). Hochschild uses the metaphor of acting methods to describe these two approaches: the Stanislavski school for surface acting and the Method school for deep acting. Hochschild frames emotion work as a private act influenced by larger social and cultural norms (feeling rules) in which one matches what one internally feels to what is considered appropriate to feel and express.

Hochschild distinguishes emotional labor as the private process of emotion work being transferred to the public world of work (Wharton 2009). In describing the process of emotional labor required in paid labor situations, Hochschild argues that management disciplines workers to provide more than their physical labor, but this part of themselves that exists outside of a professional context ideally should be protected from being managed. These demands of masking one's "true" self in a labor context, either on a surface or deep level, is stressful and leads to consequences such as burnout.

Hochschild's work helps to further understand the internal dynamics in living groups in squatted houses because she describes expectations that are present but become invisible because they are not discussed. She also describes how in situations where emotion work is necessary, people adapt themselves to such demands, internalize them, and perform them without explicitly naming this process of management. Hochschild sheds light on the emotional gymnastics one undergoes in a space that is ideally intimate and safe, but because it both constitutes and is the product of a social movement with its own criteria for capital, subcultural performance expectations, and a housing crisis, such a space is infused with multi-layered power dynamics. The ethnographic portraits of hierarchical dynamics within three squatted houses illustrate these points.

\section{Frank and Janny}

Housemates who have squatter capital in the movement and who originally squatted a house have the capacity to hold notable authority over a living group if they desire to wield it. Frank and Janny, both veteran squatters, had organized the squatting of a three-story building, which featured eight 


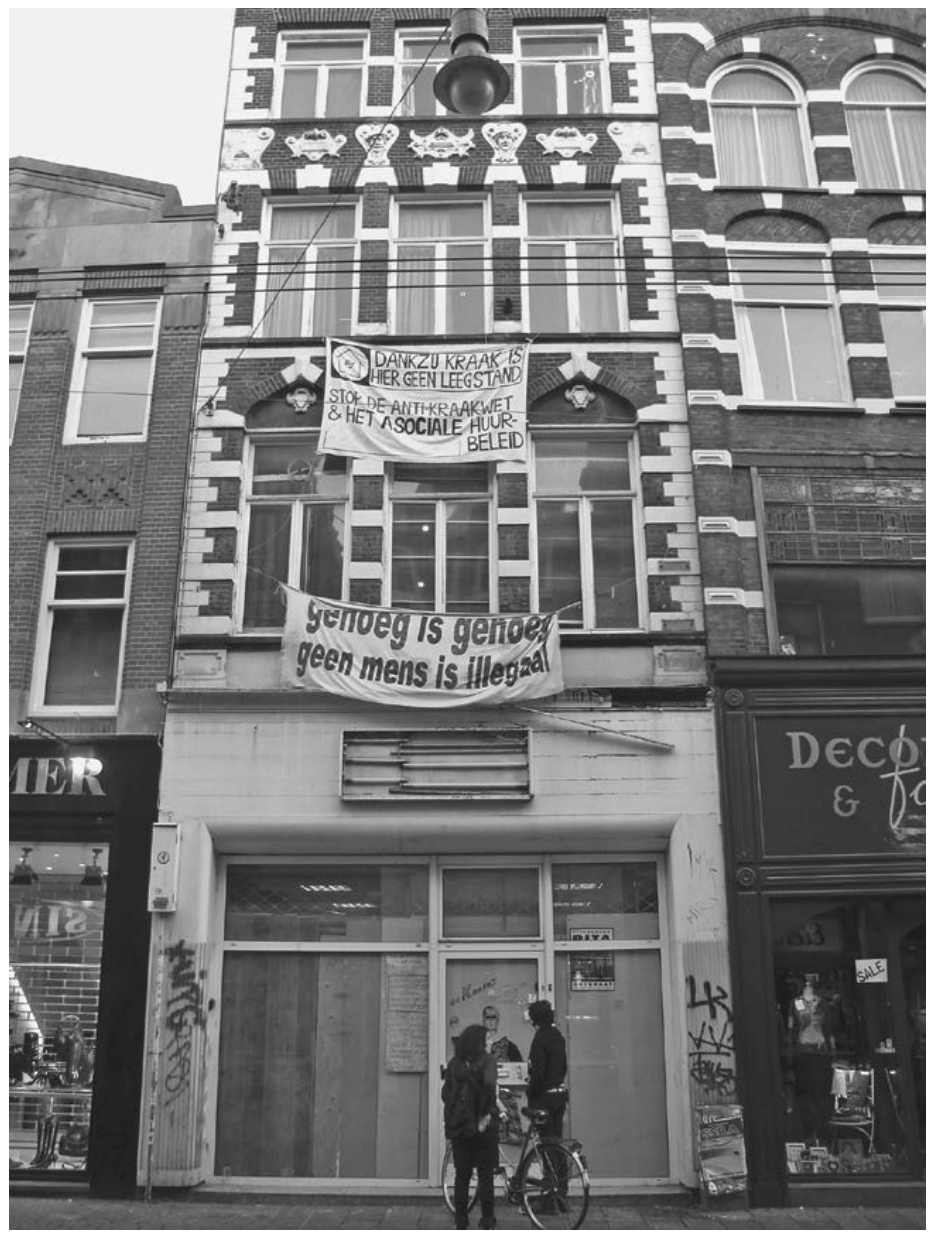

Figure 3.2 The "Leidsbezet," a squatted social center in the center of Amsterdam, 2006

bedrooms and an atelier. They refurbished it into a magnificent building, which exhibited better conditions than most rental property in Amsterdam. Over the years, the living group comprised a revolving door of housemates. Given the housing shortage, I never understood why so many left an immense, beautiful, building with sizable rent-free bedrooms that could easily have been rented for hundreds of euros a month. After spending considerable time with this group helping them with their campaign, I learned that the hidden expectations for being a member of this living group could potentially cost more energy than the time and effort entailed in paying rent.

As the people who had originally squatted the house, Janny and Frank silently occupied the positions of most authority. Miles, a former housemate 
comments, "Janny and Frank are the heart of that house. They are the axis on which that house and the living group turns." After having squatted a number of houses and lived in squatted living groups throughout the Netherlands, Janny and Frank decided to carefully choose their housemates for this particular squat. They wanted housemates who participated in the political aspects of squatting, took responsibility for the house by reliably conducting maintenance and ensuring that the gas, electricity, and water functioned properly. They also sought housemates to create a "cozy" atmosphere (cozy translates into gezellig, a Dutch word that connotes a warm, sociable, comfortable, atmosphere) by cooking, cleaning, and acting sociably within the living group. Further, they looked for potentially interesting people, such as activists, students, or artists.

This is a tall order; so, unsurprisingly, conflicts arose when housemates failed to fulfill these expectations. If the housemates were artists or students, heavily involved in these activities and their own social networks, Janny and Frank criticized their lack of participation in the squatters' community and lack of commitment to the living group. According to Frank:

No one has to participate but it's nice if they do. There is so much that people can contribute to. The giveaway shop. Going to the voku. Working at the voku. The way I see it, without the movement, they wouldn't have a place to live. But no one has to do anything that they don't want to do. It's just nice if they do.

On the other hand, when "real squatters" moved into the house who were "active" in the squatters' community and often spent the entire day lounging in the house and socializing with the living group, Janny and Frank criticized them for acting "passively." The term passive encompasses a set of behaviors, from neglecting household tasks, repairs, and finances, to an attitude of general reluctance to take initiative in their lives in the discursive Mainstream as viewed by Janny and Frank. Janny habitually criticized the "real squatters," who often resided in their house as guests after being evicted, for not studying in higher education, being habitually unemployed, lacking financial responsibility, and for allowing the squatters' community and its repertoire of actions, parties, and social centers to function as their entire social world.

The housemates who succeeded in living with Janny and Frank for the longest amount of time were two young women who effectively negotiated these unstated expectations. Amalia and Janneke were both integrated into the Mainstream. Amalia, from Finland, studied in a Master's program in media studies and Janneke, from the south of the Netherlands, worked full time as an intern for a graphic design firm. Living in Janny and Frank's house was the first time either had experienced squatter living and neither possessed squatter capital. For them, squatting, its political activities, and 
social scene provided them with an easily available social network that they appreciated as newcomers to the city. They enthusiastically participated in the squatters community by working in various institutions: Janneke volunteered weekly in the giveaway shop and Amalia served as a member of the activists' samba band. They also took responsibility for the house by working on its defense campaign, cooking, cleaning, managing finances, and periodically maintaining repairs.

Most significantly, neither challenged the authority of Janny and Frank. With Frank in particular, they skillfully placated him. When he criticized them for neglecting to clean, they never challenged him for holding them to standards that he failed to fulfill. Janneke complained to me once, "Frank just goes around, making a big mess in the house, and the three of us don't say anything. We just let him do it." Amalia told me that during house meetings, when the three women planned how to implement the house's defense campaign and allocated tasks, Frank often became upset, arguing that he felt silenced and excluded. Both women learned to appease Frank by immediately apologizing, patiently listening to his ideas, and then continuing with their earlier discussion once he felt comfortable.

Frank is a Dutch squatter in his late twenties. Trained as a filmmaker, he works during the summer, filming music festivals around Europe, and lives off his summer salary during the rest of the year. Unusually for squatters, Frank grew up in Amsterdam, the son of an architect and a school nurse, both of whom professed leftist politics. He was raised to call them by their first names and dislikes describing his class background, refusing to, as he says, "put himself into a box." As a fifteen-year-old punk sporting a Mohawk, he became involved in the squatters movement when he read a newspaper article interviewing squatters who were preparing for the eviction of their mansion. Excited, he skipped school to help with the barricading. Having spent half his life in the movement and having squatted houses throughout the Netherlands, Frank comments in his current non-punk state, "I feel at home in the scene. I feel at ease. If I'm in Amsterdam, I'm going to go squatting. It's a natural choice. I get a house and I participate in the scene that moves around it."

Frank possesses sizable squatter capital for his skills. He can break doors, build effortlessly, serve as a police spokesperson during actions, has acted courageously during countless direct actions for a number of radical left causes - a connoisseur of "scene points," and has been jailed numerous times for non-instrumental acts of bravery. During actions in particular, he exhibits an unflinching confidence in the face of danger where others may show fear. He speaks his mind refreshingly, criticizing squatters who attend meetings high or drunk whereas others feel uncomfortable and remain silent. When I interviewed him, he articulated thoughtful opinions on his motivations to squat as a protest against the dismantling of social housing, on the effectiveness of squatters' barricading methods, and his reasoning for whether or not 
to campaign to defend the squats where he had lived. He has a reputation for being well organized, outspoken, articulate, and a strategic thinker.

Upon spending time with him and his housemates by helping them with their defense campaign, I learned that Frank's squatter capital for being well organized and strategic lacked any basis and were disguised by his verbal acuity and confident persona on the backstage of the squatters movement. Frank's partner, Janny, a capable and intelligent young women with considerable skills and squatter capital, had in fact organized most of the squats from which Frank's capital derived. Although Frank believed in campaigning to defend squats and often criticized other squatters for neglecting their court cases and the political issues that surrounded their houses, he lacked the organizational skills to campaign for his own houses.

Luckily for Frank, his partner and his two housemates unobtrusively produced campaign materials, met with the kraakspreekuur for advice, lobbied politicians, conducted extensive research, prepared the legal issues, and wrote press releases, all without involving him. However, in public forum, such as the neighborhood council and at actions to support their house, Frank served as the house's spokesperson. I once asked Janny how she managed this situation in which a team of three feigned being a team of four without the knowledge of the fourth member. She replied:

During meetings, I give him space to talk for as long as possible. When it's time to divide the tasks, I make sure that he gets the tasks that are the least important and take up the most time because he has a lot of time on his hands and he is not efficient. The rest of us are working so we don't have as much time as he does. Like giving out flyers. That takes lots of time but it's not so important. The important stuff - talking to the lawyer, or dealing with the politician, things that have to be done quickly, either I do it or I ask one of the girls to get it done.

In this case, the three women were perfectly aware of their emotion work with Frank to maintain a sense of peace in the household. They self-consciously delegated public speaking opportunities to Frank to enable him to feel that he was more of an authority figure than he actually was. These women strategically acted to maintain a sense of harmony in their group and did not feel disempowered in their machinations. Janny participated in this surface acting of emotion work for the sake of her relationship. While for Janneke and Amalia, they understood that with a little emotion work to engineer Frank to feel that he was "the Big Man" (quote from Amalia), they lived contentedly in a uniquely beautiful house in excellent condition without having to organize and manage squatting their own spaces.

Frank's misrecognition in the squatters' community as having skills that he did not possess poses an interesting example to consider for a Bourdieuian framework. Frank had the privilege of two sources of socialization: his 
upper-middle-class background and the squatters movement. He disliked speaking about his class background, for example, understanding that his father's profession as an architect marked him as being upper-middle class, a classification that disrupted the overall fantasy of classlessness enforced within the squatters' subculture.

From his family background, he was inculcated into middle-class tastes and habits that enabled a subconscious recognition of affinity and competence in the hierarchy of skills and predispositions of the squatters movement. His cultural capital provided him with a sense of entitlement and confidence to speak and be heard in public settings, particularly the backstage of the squatters' scene, and to enact an oppositional self which gained him further capital since public speaking and oppositionality are highly esteemed in the squatters' subculture. Dana, a veteran squatter with significant squatter capital, unmasks Frank's confident posture whenever given the opportunity. She had once assisted him with installing gas and water pipes and found his confidence appalling. She remarked, "He's so arrogant about his abilities but he doesn't actually know what he is doing. With gas pipes, that's dangerous."

From the squatters movement, he was socialized into the movement's values, ideologies, and acquired respected skills such as building and breaking. Frank learned that campaigning to defend a house from eviction was highly prestigious on the squatters movement's backstage. To explain why he never campaigned in the past, he articulately informed me that after a careful analysis of the legal situation of the house, he realized that such campaigning was a waste of time and that as a result, he refused to conform to movement expectations. Thus, he presented himself as aware of the expectation, but having the critical awareness to evaluate it and rebuff it when it proved unnecessary. Frank refrained from admitting that he decided not to campaign because he preferred to spend his time by lying in bed in his room for days on end, watching television, and surfing the internet.

The case of Frank and Janny presents an example in which squatter capital fluidly transfers into household dynamics. Frank and Janny possessed tremendous capital in the movement and this reflected in their authority in the hierarchy within their squat. More intricate configurations of hierarchy and authority within living groups arise when a disjuncture exists between a person's squatter capital on the movement scale and one's "commitment" to a house.

\section{Larissa, Fleur, and Barbara}

Larissa is a Dutch squatter who has lived in her squat for over five years, a nineteenth-century building with four stories and an immense ground floor space. Her squat is unusual because it's considered "safe," meaning that it's 
not under impending threat of eviction because the owner fled Europe due to criminal charges of money laundering. The group who originally squatted the house intended to create a self-consciously apolitical space. According to Ludwic, one of the original squatters, "This house is for people who just want to have fun. No politics are allowed. Just fun.” Ludwic's statement indicates a rejection of a rejection, that is, a repudiation of an overly political life that is an imagined norm in the squatter subculture, which in itself is a spurning of the image of an alienated Mainstream life. Ludwic and his housemates sought to create a living group where no one felt pressured to discuss politics and thereby refusing what they considered to be the hypocritical dogmas of the squatting scene. Further, this living group consumed without showing consideration to the taste habits of the squatters movement, renouncing vegetarianism and holding bacchanalistic meat barbecues in which they reveled in eating the industrial meat that they purchased from the supermarket - versus organic meat from the natural foods store as sanctioned by the squatters' subculture. Although this living group identified themselves as apolitical, they still participated in the squatters' scene by attending squatting actions, political actions, parties, and working at the social center.

The living group of six people comprises a mix of veteran squatters and people without experience in the squatters movement, and thus, no capital. Larissa, an assertive and outspoken Dutch woman who studies urban planning and writes poetry, is a senior member of the group despite not having squatted the house initially. She moved in six months after the original group had already extensively repaired the house (that is, built floors, walls, a kitchen, two toilets, a bathtub, a shower, installed gas, electricity, heating ducts, heaters, plumbing, and insulation), successfully defended it from the owner's thug friends who periodically broke their windows until the squatters confronted them, as well as won their court case. Compared to the veteran squatters in her living group and because she missed the confrontational and labor-intensive aspects of squatting her house, Larissa possesses limited squatter capital.

Unusually in the squatters' community for someone in a position of authority, Larissa speaks openly about the hierarchy in her living group:

The house is mine and Solomon's [the person who originally squatted the house, organized the action, repaired the building, and won the court case]. Fleur is never here and yeah, she's good about squatting stuff, but otherwise, she's never here. She's so lazy in so many ways about the house. She never cleans. And the others are, you know, the others. The perfect housemate though is Barbara.

Fleur, Larissa's housemate, is a young Dutch woman who possesses all the components of squatter capital (see Chapter 2 describing Fleur as a 
spokesperson): she's a breaker, she can build, she is well organized, she is an articulate spokesperson, she's strategic, and she has participated in violent actions in which she performed non-instrumental acts of bravery. Because she has a career as a commercial ship's officer, she spends less than half of the year in Amsterdam. As a result, Fleur is well known in the squatters' community and retains capital for her skills and past deeds but, within her living group, she is less valued because she does not "show commitment" due to lack of emotional investment and by neglecting household chores. Fleur still has more authority than her housemates without seniority and capital, as illustrated by Larissa's quote, "and the others are, you know, the others." But in the delicate power relations within a squatters' living group, she has less authority than Larissa and Solomon due to her frequent absence and general lack of "showing commitment" to the living group and the house itself. Larissa's dismissal of Fleur ("She's so lazy") also points to Fleur's extensive capital in the movement in that only authority figures on the level of the movement are actively disparaged (see Chapter 2). Furthermore, Larissa's description of the house as "mine and Solomon's" is both refreshing in its openness as well as another indicator of the hierarchy. It shows that she holds a position below Solomon, who is the person with the most authority in that house but would never openly admit this fact.

Lastly, Larissa's mention of Barbara in this quote significantly demonstrates the meanings of "showing commitment." Barbara is a young Dutch woman in her early twenties who came to Amsterdam to train as an elementary school music teacher. Through her network, she first lived as a guest in Larissa's house and eventually the living group invited her to stay as a housemate. Barbara has no squatter capital and although my interactions with her were brief, she entirely lacks an oppositional habitus. Instead, her overall attitude is of someone who seeks to please others. Despite her lack of squatter capital, Larissa and her housemates valued Barbara because she did household chores without complaint, was socially available and pleasant, participated in the group without challenging authority, and avoided creating conflicts. Thus, Barbara's qualities as a perfect housemate in which she treated people kindly, was socially warm, avoided conflict, and effortlessly did household chores were antithetical to being a "real squatter" where the performance of a constant hostile oppositionality symbolizes sincere political conviction.

\section{Gerard and Allen}

Gerard, a German man in his mid-twenties, came to Amsterdam to study in the Dutch university system. Through informal contacts, he met a group of people who were preparing to squat ten houses located in a housing complex on the outskirts of Amsterdam built in the 1970s for the workers of the 
nearby municipal jail. Because most of the workers did not want to live in these houses, half of the houses were empty for over five years before they were squatted. ${ }^{2}$

For Amsterdam, these houses were unique. They were spacious, with four bedrooms, a living room, two bathrooms, storage space, an open kitchen, a balcony, and an enormous garden. Squatters found them especially appealing because the owner, the municipal jail authority, had not destroyed the structures and utilities as is the common practice of owners to deter squatting. As a result, the houses were ready to live in without a need for refurbishment.

The squatting action of the ten houses was ambitious and immense. Although different groups had organized themselves to live in the various houses, the whole action - that is, the research, the organization, the breaking of the doors, the consultation with the kraakspreekuur - were all coordinated by a Dutch organizational management student, Deanna. ${ }^{3}$ Deanna carefully selected the residents, avoiding "people with dogs," a.k.a. crusty punks. Instead, she sought squatters who were students, musicians, dancers, theater people, and visual artists.

The physical location of the houses on the outer rim of Amsterdam and the lack of activist squatters alienated most of the residents from the more entrenched activist squatters' subculture. When this complex of houses is mentioned, squatters who identify as activists scoff that the residents are lazy, artistic, hippies who squat only for free housing. They criticize them for failing to politically campaign, legalize the houses, or create a more vibrant squatters' community. The complex's residents claim to refuse the ideological and behavioral norms of activist squatters by retaining a low profile in the eyes of the state so that they can, in fact, live in these houses for free and dedicate themselves to their art and studies. When pressed to participate more in the political areas of squatting, the residents reply that they avoid politics because they believe that the city housing authority has forgotten the houses and fear that the publicity resulting from political or social activities will lead to eviction.

Gerard was one of the students who Deanna allowed in the group. He initially lived for one year with a random living group. Having no squatter capital, he felt uncomfortable, disliked the authority figures in his living group, and general movement culture. Compelled by his dissatisfaction, Gerard decided to squat an empty house on the complex with Paul, another man who sought his own space. Because Gerard had organized the squatting of this house, he felt more comfortable and more ownership of his new house. He and Paul invited Allen, a Spanish photography student, to become a housemate. Within a year, Gerard and Allen were the only housemates left since Paul spent most of the year traveling around the world to organize performance art pieces. Gerard used his authority as the only person who originally squatted the house in a way that the Dutch 
classify as "anti-social." In addition to his own room, he took over the living room as his private study, often borrowed money from Allen without paying him back, stole bikes from his non-squatter neighbors, and stole from the private rooms of his housemates, understanding that no one dared to confront him.

Gerard holds a more extreme opinion from his fellow squatters because he actively disavows the movement and does not justify his lack of participation in radical left politics. He states, "The only thing that I have in common with squatters is that we all use the same loophole in the law." Coming from a lower-middle-class family, Gerard describes himself ironically as aspiring "to be a capitalist." When discussing his career plans, he continues semi-ironically, stating, "This is how I plan to conduct world domination." By calling himself a capitalist and using such language, Gerard demonstrates that he understands that openly discussing the desire to accumulate wealth is unacceptable among the European radical left. Thus, he shows that he understands and spurns the conventions of the squatters movement but in a different modality than what is acceptable in the squatters' subculture. In the squatters' subculture, the path to sovereignty and authority lies in dismissals of dogmas while still maintaining a general anti-capitalist perspective. Furthermore, he squats because it benefits his lifestyle in that he receives a uniquely spacious house rent-free, but he hides his living in a squat from his friends because he dislikes the radical left and feels ashamed of being a squatter.

Gerard's refusal of the unspoken assumptions of the squatters movement nearly cost him his home. One summer, he arranged to rent his room to a student while he was in Germany. His housemates learned of this arrangement and forbade it. If he had rented out the room and news of this rental had reached the activist squatters, the activist squatters would have evicted him immediately with or without the permission of his housemates. Twenty squatters would have shown up at his house, moved out all of his belongings, and changed the locks. They would have told him that he had broken a sacred rule and then exiled him from the scene. They would have enjoyed evicting him.

I know all of this information from Gerard and from Gerard's housemate, Allen, the photography student from Spain who, contrary to Gerard, embraces the squatters' subculture. Although Alan lacks the skills that comprise most forms of squatter capital (breaking, building, organizing, and strategic manipulation), he frequently participates by cooking in the voku, working at the bar, helping others build, consistently attending weekly squatting actions, helping occupy squats during their first two weeks when it's still possible for the police to evict, and assisting with barricading. His squatter capital consists of his enthusiastic though unreliable participation versus capital based on skills that derive from long-term commitment, or from taking initiative and responsibility. 
Frustrated with living with Gerard and too afraid to confront him, Allen complained incessantly about Gerard and his attitude towards the squatters movement to his friends in the social center. Allen's friends, including myself, after listening for months to his complaints, encouraged him to kick Gerard out of the house. Allen, vacillated, stating that he did not feel entitled to make such a decision since he was not a "real squatter," having moved into the house after it had been squatted. Allen asked the kraakspreekuur for advice. Jeremy, a member of the kraakspreekuur with over fifteen years in the movement and ample squatter capital, responded:

The guy is an asshole but he hasn't done anything wrong. Yeah, he wanted to rent out his room but you guys did not let him. Other than that, there is no reason for us to interfere. If you want him out, let us know and we'll help you, but without that decision, no one is going to punish this guy for being an asshole. He squatted the house and he has the right to be a prick about it if you guys let him be this way.

In the case of Gerard's house, despite his dismissal of the movement and its norms, the value prevailed that the person who had organized the squatting action holds the most authority and only in extreme cases - such as renting out a squatted space - can this person be kicked out. To be clear, although no one interfered with Gerard, his behavior has social consequences. Most likely, because he wanted to rent his room but was stopped by others and thus not showing a consciousness of the lack of ethics of such an act, he will not be able to squat again with the help of any kraakspreekuur in the city, putting him on the equivalent of a squatters' blacklist. Also, if and when the complex of squatted houses where he lives gets evicted, finding a group to live with or squat with him will pose a challenge due to his reputation.

\section{Cherries}

People with squatter skills are often invited by established living groups to their houses, which demonstrates the material rewards of squatter capital. Squatters who possess abundant skills on the scale of the movement transfer their capital into their status in the hierarchy of a living group. According to Solomon, "If you are well organized, responsible, and active in the community, you always have a place to live." David, a veteran squatter in his early fifties, remarked, "It's like cherry picking. You have to choose carefully to get the best of the batch." The "cherries" are people who participate in the movement with ample capital, usually as builders, campaigners, and/or are well organized and have reputations for being good housemates in a living group in the sense of showing commitment, possessing social skills, and adeptly doing emotion work to minimize conflict. Such squatters have more 
status than housemates who have no squatter capital, especially those who entered a house as guests and simply remained, relying on the fact that most people are too conflict averse to specifically ask guests to leave. In terms of their squatter skills, "cherries" are invited to become housemates with the unstated assumption that they will use their skills in exchange for a room and authority in the group. If they fail to fulfill expectations, the housemates will feel disappointed but most likely not confront openly, choosing instead to complain behind the person's back.

\section{Guests and housemates}

In squatted living groups that identify as part of the squatters movement (versus wild squatting), it is common practice to host guests for months at a time, especially if a guest is a recently evicted squatter. Such a convention reflects movement practicality and ideology. Practicality because the cycle of squatting and evictions requires a network of mutual aid in which squats within the network house each other. After evictions, squatters require space to recover from the eviction, search for a new house to squat, and have a backup space during the initial few weeks of a new squat when it's still possible for the police to evict. The ideology of this practice reflects a diffuse sense of solidarity in that squatted houses are not solely private, but communal movement spaces that ultimately belong abstractly to all squatters.

The practice of such a convention is that a hard line of distinction exists between housemates and guests. First and foremost, guests are expected to eventually leave. A housemate takes responsibility for the house and is accountable to the living group while a guest merely resides there. Different houses vary in their rules for whether guests pay for utilities or the amount of household responsibility expected. In such a situation, a guest feels less entitled than a housemate and shows consideration to the living group since guests depend on their generosity. Such careful considerations are common for long-term guests in private homes. However, in squatted houses, its further complicated because they are symbolically movement spaces and not exclusively private. Accordingly, a different set of rules exists that result in negotiations, which conform to both movement ideologies and living group dynamics.

The status of guests can create difficulties for living groups and for guests. After the successful squatting of a house that appears safe from immediate eviction, a living group is often deluged with requests from squatters and friends of friends searching for a room "temporarily." Given the amount of responsibility and work entailed in the squatting of a house, including refurbishment, repairs, legal management, household duties, social obligations, combined with the unfortunate fact that the majority of people who seek to reside in a squatted house endeavor to avoid such responsibilities, the whole 
situation is potentially problematic. If a living group permits guests to reside in a house without articulating expectations or a departure date, living groups find themselves doing all the work to enable the house's existence while guests live off their labor parasitically. It is also common for guests to simply never leave unless the living group forces them out, which proves uncomfortable for everyone involved.

These reflections arise from my personal experience and observations. In the last squatted house where I was invited as a housemate, I remember spending several hours cleaning the filthy kitchen one afternoon. While I cleaned, a seventeen-year old Finnish hacker who was hanging out in the squatters' scene after having run away from his parents, sat in the kitchen and silently watched me, never once offering to help. He had been living in this house for two months as a guest before I moved in as a housemate. After I finished cleaning, I explained that perhaps, as a young man, he had not been taught the value of helping someone doing domestic chores. I had just been evicted dramatically with another fifty people, so I also explained that if he lacked interest in household tasks, any one of the fifty squatters who had recently been evicted would feel thrilled to move into his room and gracefully assist with chores. In response to this request - which was the first time anyone had articulated such expectations during the eight months that he resided in squats - the Finnish teenager left the next day.

With the understanding that most people are not interested in "showing commitment," a guest can then acquire value in a living group and eventually be invited to stay as a housemate simply by acting responsibly and showing consideration, as illustrated in the case of Barbara, the "perfect" housemate of Larissa. In situations where guests exert themselves to "show commitment," living groups and guests conduct emotion work in which everyone is conscious of, without acknowledging openly, that guests seek to ingratiate themselves with the goal to be invited to stay long term.

To successfully show commitment entails the enactment of a series of increasingly altruistic and communal acts, from helping occupy, build, repair, cook, and clean to more risky gestures. At one large, multi-story squat, Marcus, a Dutch squatter, had been living as a guest for months while he saved money for a year-long trip to South America. He helpfully occupied, cleaned, and cooked, but the living group considered him "a loser." After three months, he asked if he could stay as a housemate and the living group denied his request. However, his status changed months later when he gave his name for the court case to evict the house. Most members of this living group refused to provide their names because doing so causes the name giver to be personally financially liable. Such an act is especially risky since squatters rarely win their court cases. Despite the general consensus that Marcus was a "loser," by taking personal risk for a communal case, he showed a level of commitment that when he asked again if he could become as a housemate, the living group was forced to accept him. 
With these dynamics in mind of authority, hierarchy, "showing commitment," the differences between guests and housemates, and the necessity and assumption of emotion work for everyone involved as a method to negotiate such dynamics, the story of Karima, an undocumented African woman living as a guest in a squatted living group, presents an interesting case to further examine the feeling rules in these spaces.

\section{Karima and the squatters}

Karima was born in East Africa and moved to the Gulf with her family as a child. Her mother fell ill early on and Karima quit primary school to take

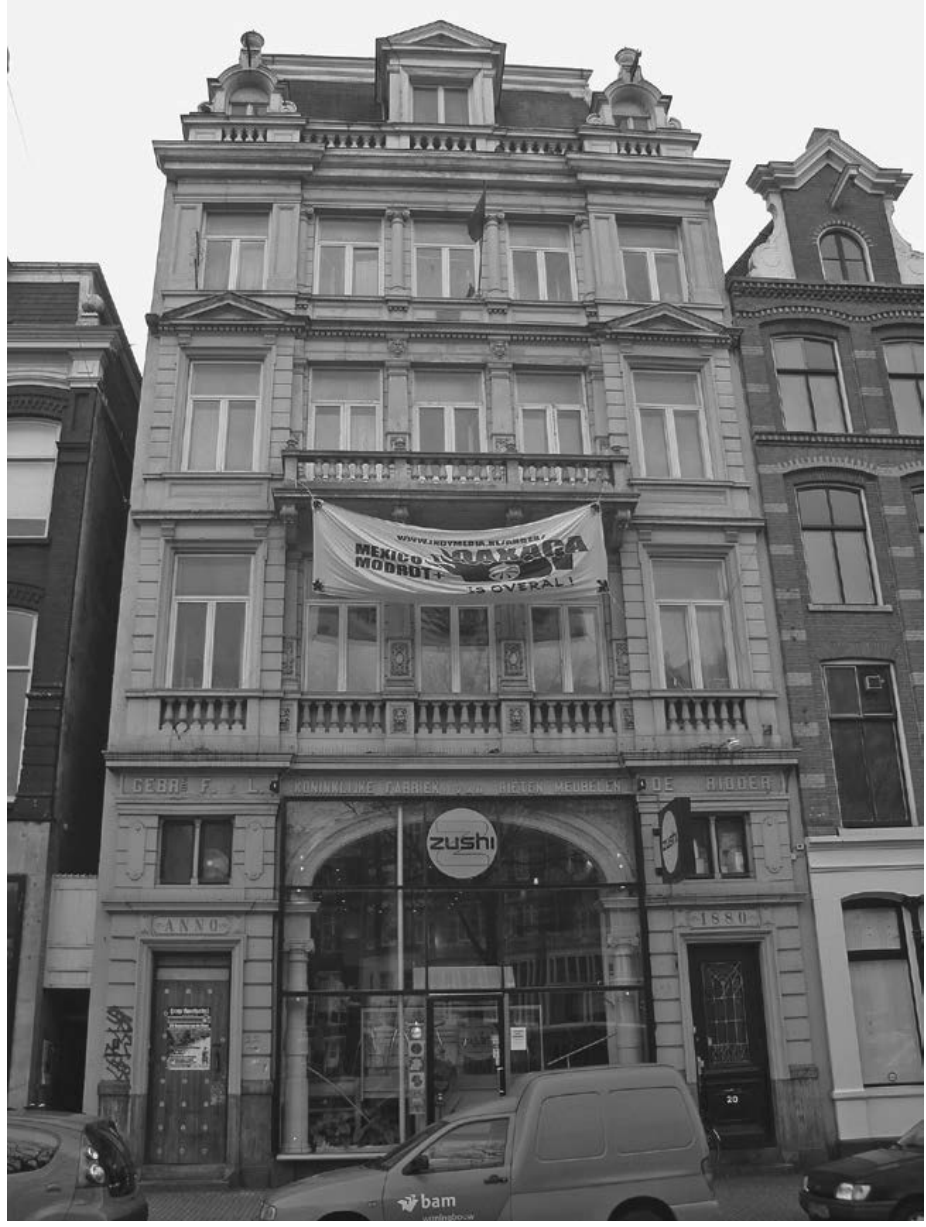

Figure 3.3 A squat alongside the Amstel River in the center of Amsterdam, 2006 
care of her family. When she became older, she worked as a domestic servant for an Arab family, residing with her employers during the week and visiting her family on her day off. She felt desperately unhappy and caged within her family and her job as a domestic servant. She did everything possible to leave her life in the Gulf with the options available to her, such as dating foreign men in the hope of marrying.

Eventually, she saved the exorbitant broker fee for transport and a tourist visa to Europe. As is the case for undocumented migrants and refugees, Karima's migration journey is mix of legal and illicit. She illegally purchased a tourist visa that enabled her to legally enter Europe as a tourist, in which she illegally intended to live and work. Border officers often treat people from the Global South suspiciously, assuming that they plan to overstay their tourist visas. With these challenges in mind, Karima arrived in France and successfully charmed immigration authorities to allow her to enter.

As Karima walked through Paris, she thought, triumphantly, "I am finally free. I have found freedom. I am in the West." Afterwards, she took a bus to the Netherlands, where she declared herself a refugee. She managed to manipulate the refugee process in the Netherlands, negotiate contacts and networks among the East African community in Amsterdam to obtain a job as well as procure a room in Larissa's living group. Her actions and behavior, although a typical story for a refugee/undocumented migrant, are extraordinary considering the constraints on her emotionally, physically, and the discrimination she faced as an illiterate, black, African woman in Europe from a low social class. Karima showed independence, initiative, and cleverness in her ability to smuggle herself from the Gulf to Amsterdam.

In the activist community in Amsterdam, it is fairly common for undocumented people to live in rooms in legalized and regular squats. However, most of the time, undocumented people only reside in squats and do not participate in the scene or in the living group, nor is there an expectation that they "show commitment." Karima acted uniquely by participating in her living group and the squatting community. She was welcomed whole-heartedly both as an individual and a symbol of the squatting community's solidarity with undocumented people, and the movement's general anti-racism and inclusivity. When Karima arrived, she told her refugee story to the living group in a gesture of honesty and supplication. She explained that she had become pregnant in the Gulf. Expecting to get married to escape her mother and her life as a servant, she found herself abandoned by her lover, an Arab migrant technician. Her mother then forced her to have an abortion, the final straw that pushed her to leave. In response to this story, the living group accepted her as a guest.

Karima contributed to her living group and in the squatters' community by diligently cooking and cleaning in her house and at the voku. In comparison to the overall attitude of reserve and hostility exhibited by squatters, she smiled, was friendly, sweet, and flirtatious. This attitude, along with her 
beauty, her tiny stature in comparison to tall and broad European squatter women, and her silence arising from her lack of fluency in Dutch and English, led many squatter men to find her attractive.

Furthermore, as a Muslim woman, Karima was a novelty. In the Gulf, she wore a burqa ${ }^{4}$ in public spaces and was chaperoned by a man at all times. In Amsterdam, she went swimming with squatters where the men swam proudly naked and her housemates teased her for refusing to wear a bikini out of modesty. Karima's novelty as a Muslim derives from the tension in Amsterdam surrounding the so-called lack of integration of working-class immigrants from Turkey and Morocco. Squatters often live in predominantly immigrant neighborhoods where women wearing headscarves and niqabs abound. Although living side by side in a relatively small physical space, a chasm exists between squatters and immigrants, especially Muslim women, who are seen as off-limits and entirely Other. Karima symbolized a world, which the squatters saw daily but could not connect to due to gulfs of culture, race, and class.

Karima, then, had a good chance of successfully living in the squatters' community and benefiting from the available support through its networks. Why then did the squatters in her living group ask her to leave despite her diligent participation and contributions to both the squatters community and to her living group? I asked Solomon, who is the unstated authority figure in this living group. He explained that despite the care and responsibility towards the house that Karima displayed by vigilantly cleaning and cooking, instead of viewing it as "showing commitment," Solomon and his housemates interpreted her housework as a result of her training to be first, a "slave" to her mother, and then, as a "slave" to her Gulf employees.

Ultimately, the housemates asked Karima to leave because they thought that she never showed interest in "an autonomous life." To prove that she was autonomous, she had to demonstrate some level of DIY qualities such as improving her English language skills, by learning Dutch, or by learning how to ride a bike. Despite the many times people offered to teach her these skills, Karima missed the opportunities and caused frustration among her living group. This living group generally permits guests for a maximum of three months but, to concede to her cultural and undocumented status, they allowed Karima to stay for six without becoming a housemate, an exception that they would never have made for a white European. Finally, the living group never felt intimate with her. Solomon and his housemates perceived her permanent smile as fake. They believed that Karima felt deeply exhausted and depressed from having fled her country and her family. Hence, Karima's positive facade disturbed her housemates, creating distance rather than intimacy.

Karima's story and the dissonance with her squatter living group reveal the consequences of the disruption of feeling rules. From Arlie Hochschild's overall framework of emotion management, feeling rules are societal 
norms about the appropriate type and demonstration of feeling in a particular situation, for example, sadness at a funeral or happiness at a wedding (Wharton, 2009). Hochschild focuses on the emotion work that people undergo to superficially project particular emotions, change their inner feelings to match the feelings rules of a situation, or how people enforce feeling rules on each other

Solomon stated that the reasons for not allowing Karima to stay were due to her insincerity and dependence (the smile masking depression and the repetition of "slave" behavior). Yet, in my description of the internal dynamics of squatted living groups, the surface acting of emotion work and the relationship of dependency between authority figures and their housemates who have less status, dominate the modes of performance within these squatted living groups. How then did Karima excessively leave the impression of insincerity and dependency in a milieu where such dynamics are rampant?

The underlying ideal of this subculture promotes communal living consisting of self-possessed, independent, and oppositionally minded individuals who treat each other as equals. The sacred feeling rule is then, that people within the movement should be able to interact as equals in which no one should feel more or less privileged. Such feelings of equality that guide relationships should, ideally, lead to people being able to speak openly and honestly to each other.

Karima's manner of presenting herself to the group clashed with this feeling rule of equality. Her openness about being undocumented, and in particular, the story of her abusive mother and the forced abortion that motivated her migration, disrupted this feeling rule of equality. Karima portrayed herself as someone who should be pitied and who depended structurally on the living group. The transparency and the necessity of the dependency, I imagine, made the Dutch squatters who made up the living group, highly uncomfortable. With this open dependency as well as her habitus and aspirations diverging sharply from the taste cultures of the squatters movement, the living group could not trust her because her dependency, vulnerability, and lack of openness tainted her actions.

Even if Karima had not presented herself as pitiable, the same problems with Karima as a housemate would have persisted. This is because the very body of Karima, her undocumented status, her vulnerability as an underclass, black, East African woman, and her lack of education, disrupted the feeling rules of equality between the housemates and their visions of anti-capitalist bohemian communal living. Her presence inserted into this household the disturbing world of undocumented migration into Europe resulting from the inequalities between the Global North and South. She impeded the fiction of classlessness and the invisible normativity of the comforts of the welfare state, in which European squatters partake without acknowledging the privileges and the overall sense of security that they receive from their entitlement to it. 


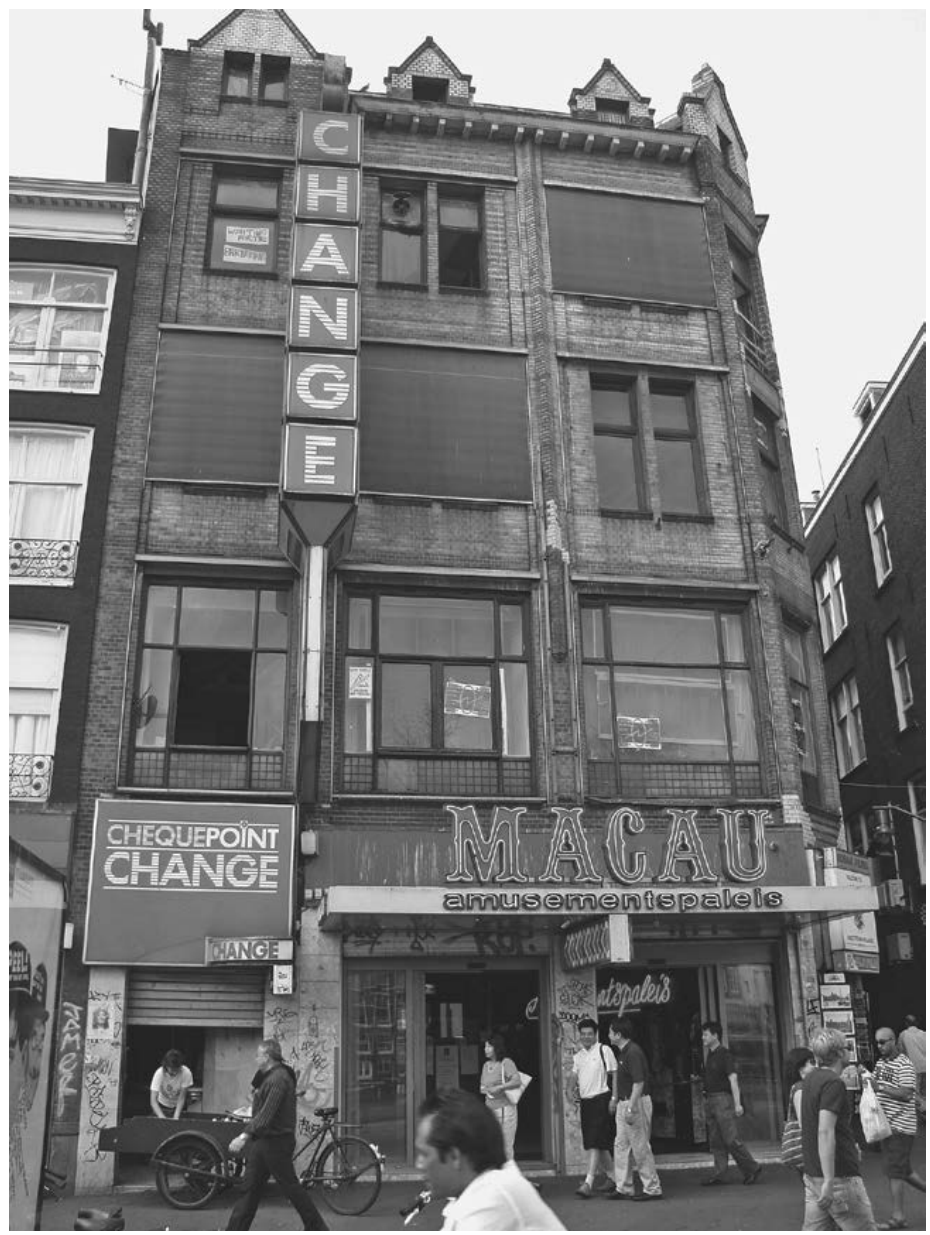

Figure 3.4 Building on the Damrak, where ground floor space was in use commercially while upper floors were squatted, 2006

As a symbol of these global political realities and their intrusion on the fantasy of the anti-capitalist bohemian squatter life, Karima paradoxically worsened her situation because she veered from the usual behavior of undocumented people in the squatters movement as shadow figures who use its resources but do not participate in the community. Because Karima sought to create emotional bonds with other squatters, interacting with her only increased the awareness of the inequality, vulnerability, and dependency rather than relieve it.

This was particularly the case because she had a number of squatter lovers. A diversity of lovers is common in a community that values multiple 
partners but the style with which she had the lovers, again, reflected her structural vulnerability. It was clear to everyone in this community, including myself, that she sought to marry for citizenship. Again, failing to understand the cultural and political norms of this community, she conducted her search in a way that counteracted her goal instead of helping to achieve it. Rather than stating openly that she sought a marriage partner for citizenship, for which she could have then found someone willing to participate (marriage/partnership for European residency is commonplace in the left activist community), she dated various men hoping that they would fall in love with her and then want to marry her. Such a plan in a radical left squatters community was destined to fail. First, marriage is seen negatively as a bourgeois, Mainstream, and oppressive institution. Second, a number of young men in this community are not interested in commitment, structural responsibilities, paid employment, nor do they want nor have the capacity to manage the bureaucracy required to enact such an operation. Karima's general impression of insincerity reflected an unawareness of the multiple and unstated rules of this community that someone in her position could not understand, leading to her being asked to leave.

\section{The consequences of no authority}

With this context of silenced hierarchy and authority, it is helpful to explore the consequences of no one taking positions of authority or leadership in squatted households. I will first use my personal experience with such a household as an example to consider this question, an experience from which I do not pretend to have any objective distance.

To situate myself in the schema that I present in this chapter, I occupied different positions along the hierarchy. Over a period of two years, I lived in four squatted living groups. In the first house, I moved in initially as a guest and the living group eventually invited me to remain as a housemate. At the time that I moved into this squat, the little squatter capital I possessed came from having worked as a cook in the voku for six months prior in which I showed that I was reliable, responsible, and a good cook. In collective projects like vokus, it is difficult to find people who commit to a project by consistently arriving every week, on time, to enable its occurrence. During the year and a half that I resided in this first house, I accumulated further squatter capital with the acquiring of organizing and strategic manipulation skills. I formed an integral part of the team that developed and implemented the house's campaign against eviction. I also often cooked for actions, participated in squatting actions weekly, and regularly attended radical left political actions every few months.

After this house was evicted, I resided as a guest in a squatted house but left after several weeks due to the oppressive atmosphere created by a 
sadistic emotional relationship between two of its inhabitants. At that point, I had been planning to squat my own house but lacked the time and energy to prepare an action because I felt desperate to leave the second house. I was then offered my own flat in a block of squatted houses where I lived for two months. Although I shared a kitchen with another person, I did not feel that we formed a living group since we each had tremendous personal space. This block of houses was subsequently evicted in the most violent and unexpected eviction of squatters in nearly thirty years, in which I was present and left scarred and shaken

Prior to that eviction, another living group had already invited me to live with them. I knew the two authority figures in this group, Roel and Marie. Marie was a veteran squatter whose capital was based on having lived in a number of high profile social centers in the past ten years and was known as highly organized and intelligent. Roel was an exceptionally skilled builder. $\mathrm{He}$ was an amateur plumber, heating engineer, electrician, and carpenter. They lived in a sprawling squat of four stories with multiple bedrooms. Bored and frustrated with living alone, Marie had squatted this space to live communally. Unfortunately, with the exception of Roel, she had assembled a group of housemates who squatted to avoid rent, paid employment, household responsibilities, financial accountability, and whose priorities were to party, use drugs, and travel. After the squatting action, Marie and Roel found themselves responsible for the tasks necessary to enable the house to exist: from managing the legal aspects, negotiating with the mafia owner, to constructing floors.

Four months after they had squatted the house, Roel and Marie invited me to move in as a housemate. Although they never openly stated this, I understood that they needed someone who was organized, reliable, had campaign skills, and would not feel intimidated by the aggressive owner. They offered me one of the most spacious and loveliest rooms in the house (displacing one of the deadbeat housemates to a smaller room) and since the house was not under eviction threat, I took their offer. I lived in this group in a position of high status although with less authority than Roel and Marie.

During the first two months, I cleaned the house physically and metaphorically. I cleared out rotting old furniture, replaced it with cleaner and more attractive furniture that I had found on the street, threw out unused items that cluttered the space, and put down rugs to cover the stained and ancient carpet. I removed the decrepit wallpaper and decorated the common areas with plants. I converted an unused space into a dining room and cleaned out closet spaces throughout the house that were filled with items from years before the house had been squatted. I painted the bathroom walls and replaced the rotten linoleum in the toilet, which stank of years of urine (we wore face masks while removing it, during which Roel yelled, "It stinks of the pee of a hundred old men!"). Before I moved in, the electricity and the gas originated from a hacked source. I arranged for the group to pay 
for the utilities instead of stealing it. I set up an internet connection. I also contributed to the group's cohesion because I cooked almost every night leading to the group habitually eating together.

Metaphorically, I cleaned the house of the many who viewed it as a crash pad to hang out, party, and use drugs. This cost more energy than the physical cleaning. Despite Roel and Marie's extensive experience and skills, both avoided conflict. Consequently, the house was filled with random guests who considered the space their private lounge area in Amsterdam.

After having lived in and spent time in squats that were more structured and selective regarding who they permitted inside their houses, I found these strangers unbearable. Leaving for work in the morning to encounter someone passed out in front of my bedroom door, coming home from my university job to find random French hippies in a multi-drug stupor in the living room who had eaten all the food that I had purchased the day before, or waking up screaming at 4 a.m. to discover a stranger in my bedroom who was walking through the house playing a portable radio at full blast - I found this situation intolerable. Marie's solution was to never spend time at home, sleep elsewhere, and complain to members of the squatters' community. Roel was also never home, being an avid drug user in which he passed the days at party squats. Even if they had been present, both were unwilling to confront these people and set limits. Instead, they hid in their rooms.

I strove to get rid of these people without explicitly kicking them out. As per the earlier story, the Finnish teenager left once I asked him to help with household chores. There was a common space that had been empty except for a mattress where people slept after partying and using drugs. I cleared out the mattress, installed a dining table and bureau, and transformed the space into a dining room. Throwing out the filthy furniture also removed further "crash" areas. Having connected the utilities and the internet to the house, I introduced the idea of housemates and guests contributing financially, which led to more people leaving. I continually set limits until the only people left were those who were responsible, reliable, and considerate. Afterward, I changed the locks.

Despite the effectiveness with which I enacted these changes, the experience was horrible. I had moved into this house in a traumatized state from having been evicted in the middle of the night by the police, dealing with the hysterical behavior of the squatters during the siege, the claustrophobia of being in jail, as well as having to re-obtain my impounded belongings. Instead of resting from the exhausting shock of this experience, I found myself in a situation in which I had to bully out random people without support from the authority figures in this squat. Although both Marie and Roel told me in private that they felt pleased with the changes that I had made, they hid behind my straightforward character to maintain friendly relationships with the people who I was pushing out and therefore, hated me. 
My personal experience with having to perform the taxing role of setting limits and managing the space made apparent the necessity for leadership within a squat. I also understood clearly that for many people within this movement, the challenge of transgressing the feeling rule of equality, and settling limits and boundaries proves so difficult that the squat itself becomes vulnerable. Moreover, for many in this movement, this feeling rule of equality and the corresponding rejection of any form of authority within a squat, is so sacred that a squat becoming chaotic and unsustainable is preferable than taking a leadership role.

After this experience, I understood the process behind a term that I have occasionally heard, "when squats go wrong." I had heard comments such as, "Everything is fine in the Motorflex. It hasn't gone wrong." This expression is a euphemism for squats that have transformed into locations for using heroin. I realized that this transformation results from an internal dynamic in which no one takes a position of authority within a squat, thereby allowing a wide variety of people to use the space, leading to a space becoming a "junkie house."

Among activist squatters, heroin is taboo and becoming known as a heroin addict means losing one's capital entirely. One of my first interviewees, Jacob, who had been an active squatter as a teenager and then left the movement after five years, mentioned his involvement with a squatted orphanage with beautiful gardens that housed 120 people, which he euphemistically described as "disorganized." When the group who had organized the space were bought out with replacement housing and cash, a small group of ten activist squatters remained. According to Jacob, this group was "invaded" by "disorganized people," whose main interest was to avoid paying rent and who refused to contribute financially to the house. Many had serious drug problems so that the house developed into "a problematic area," where Jacob saw disturbing things, such as "junkies half dead in the hallway" and people "putting baskets full of shit in their fridge." After the house was evicted, the police discovered a dead body in the basement.

I had heard other stories of "squats that go wrong." Carlos, a Slovenian squatter, said to me once, "I've seen it so many times. One guy or girl in the house starts doing heroin. Then this person gets a boyfriend or girlfriend and they do it together in the house. Next thing, everyone in the house is doing it. It becomes a junkie house." I asked two veteran Spanish squatter friends about their experience with "squats that go wrong." Miguel, a Spanish squatter, initially replied, "If someone does heroin in a squat, the group kicks him out." I pressed, not accepting this answer. Marta then added, "That's not true. What happens is that for junkies, it's hard to find places to do it with other people. So once they find a place, more and more go to that place and do it there. Before you know it, you are the only one left and the house is filled with junkies. You have to leave, not them." 


\section{Conclusion}

Mapping the cartography of power dynamics within living groups who identify as part of the squatters movement in Amsterdam is fraught because of the incompatibilities between imagined ideals and silent practices. The ideology of the movement rejects property as "theft." Meanwhile, the silent practice is that those who squatted a house have the most authority and "own" the house in the social logic of the movement. Furthermore, the behavior and skills that contribute to one's status in a household are related to but not necessarily the same as those that add to one's capital in the movement. With some skills, such as building and campaigning, one's capital in the movement transfers fluidly into one's status in a living group. However, the oppositional, argumentative, persona that holds merit in the movement's public spaces should be suspended in the private sphere to avoid conflict and maintain a peaceful and "cozy" group living environment.

Squatted houses present a convergence of the public and private in a dramatic way. On one level, these houses are private spaces, where ideally a resident should feel comfortable in a convivial and warm living group, which provides a safe haven from urban alienation via an alternative to the nuclear family. However, they are also public spaces in that they both constitute and are produced by a social movement. Hence, movement capital of individual residents impacts the micro-social dynamics of the group. Further, these houses are spaces for socialization, skill acquisition, and are in fact, organizations in which the participants must cooperate and take responsibility for tasks to enable the houses to exist and run effectively.

Returning to Hochschild's emotional management, she distinguishes between emotion work and emotional labor, stating that the first is primarily a private act influenced by broader social and cultural norms that define feeling rules while the second is a process directed by management in a paid labor context (Hoschschild 1979). Squatted houses complicate this distinction. The ambiguity between private and public in these squatted houses, the expectations around "showing commitment," the denial of hierarchy and authority in these spaces while silently maintaining these power dynamics, combined with the housing shortage; all of these simultaneous factors make it difficult to distinguish between emotion work and emotional labor.

With such contradictions in mind, does this social movement community offer emancipation on any level beyond a discursive one? Do the feeling rules of equality that dominate the emotional landscape offer liberation from the shackles of Mainstream life from which many of this movement's participants seek to flee? The case of Karima and the examples of squats where people refuse to enact authority leading to their transforming into "junkie houses," present cases when the feeling rule of equality, so sacred to a non-hierarchical, anti-authoritarian social movement community, are 
explicitly challenged. For Karima, she framed herself as someone to pity and care for rather than as a self-possessed, oppositional activist. This led her squatter housemates to feel that she overly depended on them. Despite the numerous cases of dependency and unequal power relations that prevail in a squatted living group, her inability to perform "autonomy" led the housemates to feel uncomfortable to the point where they asked her to leave.

In houses where no one enforces authority, such as the last squatted house where I resided and houses that eventually become overwhelmed by heroin users, the requirement that one or more people, usually those who originally squatted a space, claim their authority by openly setting limits and standards on the behavior of others, confront conflict, and position themselves as figures of potential dislike, the prospect of refuting this revered feeling rule of equality proves overwhelming. Rather than dispense even temporarily with the feeling rule of equality and the paragon of a warm, "cozy" atmosphere, squatters would rather abandon the space in search of new opportunities to be "autonomous."

\section{Notes}

1 I distinguish between living groups in squatted households that identify with the movement versus squatted houses which make no claim to being part of the movement, including wild squatting (see Chapter 1 for definition of wild squatting).

2 These houses further complicate the definition of "squat" since most of the tenants who were employed at the jail had stopped paying their rent for years before the squatting action.

3 Deanna was the de facto queen of this squatters' village, to the extent that approximately two years after the squatting of these houses, she moved to Finland permanently. However, she left her belongings throughout the house and retained her room - and demanded that no one else live in it - so that she could stay in her room during her vacations to Amsterdam. Her housemates never challenged these demands but complained about them to others in this community.

4 I learned this detail from Karima's Dutch housemates. However, it's unclear what type of head covering Karima factually wore in the Gulf because in the Netherlands, people colloquially refer to all head coverings as burqas. This term is inaccurate since burqas are predominantly worn by women in Afghanistan. In general, Dutch discourse does not distinguish between various head coverings worn by Muslim women around the world and their symbolic connotations. 